\title{
STRENGTH AND PERMEABILITY CHARACTERISTICS OF EXPANSIVE SOIL WITH GYPSUM AND RICE HUSK ASH
}

\author{
*Angelo B. Edora ${ }^{1}$ and Mary Ann Q. Adajar ${ }^{1}$ \\ ${ }^{1}$ Gokongwei College of Engineering, De La Salle University, Philippines \\ *Corresponding Author, Received: 11 Nov. 2021, Revised: 01 Dec. 2021, Accepted: 18 Dec. 2021
}

\begin{abstract}
The presence of expansive soils in the site poses threats not only for built residential houses and superstructures but also for roadway construction. The shrink-swell behavior of expansive soils creates a continuous strain on the pavements which can result in cracking and settlements. Therefore, there is a need to stabilize such problematic soils. This study aims to establish a more economic and environmental-friendly way of stabilizing clay loam from Kauswagan, Lanao del Norte. Varying combinations of gypsum and rice husk ash (RHA) were used in soil stabilization. Untreated and treated soil specimens were tested for their California Bearing Ratio (CBR) and coefficient of permeability per ASTM Standard D1883 and D2434 respectively. The CBR of the soil slightly increased with the addition of $15 \%$ gypsum. While the addition of $10 \%$ RHA with the same amount of gypsum dramatically increased the soaked CBR index of the soil. A peak average value of $21.11 \%$ was recorded for $15 \%$ gypsum $+10 \%$ RHA soil specimen. Falling head permeability tests showed that as the amount of gypsum in gypsum $+10 \%$ RHA soil specimen increases, the coefficient of permeability of the soil also increases. A direct relationship was then formed between strength and permeability. This can be attributed to the formation of micropores in the soil specimen with the addition of $10 \%$ RHA, allowing an easier flow of water through it. The stabilized soil passed the DPWH Standard for the subgrade layer but slightly fell short of the requirement for the subbase layer.
\end{abstract}

Keywords: Expansive soil, Roadway construction, CBR, Permeability, Soil stability

\section{INTRODUCTION}

Expansive soils are characterized for their drastic volume change depending on the water present in them [1]. This behavior is attributed to the most detrimental clay mineral in expansive soils which is the montmorillonite. Expansive soils exhibit three characteristics that are considered problematic in construction - expansiveness, crack, and over-consolidation. These characteristics are highly dependent on the amount of water or moisture in the soil and may manifest during drywet cycles [2]. Excessive expansion and shrinking of these soils produce continuous ground movement which causes multiple damages to the overlying structure. Also, the propagation of cracks in the soil reduces its overall integrity and strength and increases its sliding ability. Another thing to consider is the over-consolidation characteristics of these soils which hinder the drainage of tightly packed particles of soil. In solving these, soil stabilization techniques are implemented to improve the properties of the soil and make it more suitable for its served purpose. The use of heavy equipment and mechanically stabilizing the soil onsite are the usual ways of improving the strength properties of soil however, these practices have various negative impacts on the environment and are not economically possible for all instances. One of the more economical ways of stabilizing soils is chemical soil stabilization. This is done by altering several properties of the soil by incorporating additives, to improve the necessary parameters for engineering purposes. Cementitious materials such as cement and lime are the typical characteristics of additives used. However, the use of cement in soil stabilization contributes to the rising carbon footprint of construction. Therefore, the use of waste materials exhibiting the same properties is the focus of research nowadays to promote sustainable construction.

Gypsum is known for its application in the flash setting of cement however, the larger percentage of use of gypsum is in the production of plasterboards. In Japan, the sudden rise in construction demand increases the consumption and disposal of excess and under quality plasterboards which poses environmental problems in their country [3]. With this, an opportunity to use it as a soil stabilization additive was established by past studies [4],[5]. It was found that gypsum combined with rice husk ash (RHA) was able to improve the strength properties and control the expansion of expansive soils [5].

Agricultural wastes such as RHA were also used in soil stabilization techniques because of their abundance. In the Philippines, the top ten riceproducing provinces produced nearly about 9 million metric tons of rice per year which can also be associated with the huge amount of rice husk waste. The viability of RHA in the field of soil 
stabilization was proven by past studies [6],[7]. It was found that RHA has pozzolanic properties due to its silica and aluminum content. This characteristic is important in the development of the strength property of soils.

The main objective of this study is to determine the optimum mix proportions of waste gypsum and RHA that will yield the maximum values of the strength property and permeability acceptable for roadway embankment application. In determining the improvement on the strength property of the soil, CBR tests are done using untreated and treated soil specimens. On the other hand, falling head permeability tests are done in determining the mix proportion of gypsum and RHA that yields the peak value for the coefficient of permeability. Empirical models are then formulated to describe the relationship of soaked CBR index and coefficient of permeability with the amount gypsum in a mixed proportion.

Given the results of the recent study of [5], this study focused on the uncovered areas of their study. Specifically, this study determined the applicability of the gypsum + RHA stabilized soil as a road embankment material by considering its strength and permeability properties.

\section{RESEARCH SIGNIFICANCE}

With the implementation of the 'Build, build, build' program of the government, the demand for construction materials and the waste generated including gypsum increases. And considering the effect of gypsum on the environment, this increase in a waste generation may cause environmental problems in the future [8]. Considering the country's rice production, using RHA in stabilizing soils is ideal. This promotes a more sustainable, economical, and eco-friendly way of improving the geotechnical properties of soils. Additionally, effectively stabilizing expansive soil and determining its response to gypsum open new stabilization methods for expansive soils that have similar properties.

\section{MATERIALS AND METHODS}

\subsection{Source of the Expansive Soil Sample}

The soil sample used in this study was extracted from Kauswagan, Lanao del Norte, Philippines. The sample was extracted at a depth of at least 2 meters ensuring that no organic matter will be included. The area was used for a proposed landfill site. While dealing with moist samples, color streaks and some of the soils were left when forming bigger clumps of soil as seen in Figure 1. These traits were attributed to clay minerals in soils [9]. On the other hand, the soil exhibited cracks and loss in total volume when oven-dried for 24 hours at 105 degrees Celsius as can be in Figure 2.

\subsection{Source of Gypsum}

The gypsum used in this study was sourced from a hardware store, selling it as plaster. This form of gypsum was grounded to powder and heated in production plants at a temperature depending on their application. Typically, gypsum wastes are collected from plasterboard excess and rejects during production. These wastes are then recycled by recycling companies and repurposing for plaster and tile grout used. Figure 3 shows the gypsum used.

\subsection{Source of Rice Husk Ash}

The rice husk ash used in this study was collected from a biomass powerplant in Muntinlupa City, Metro Manila. Huge hauls of rice husk from the Central Luzon provinces were collected and brought to the said powerplant to incinerate. The resulting product of the said incineration process was the rice husk ash. Figure 4 shows the rice husk ash used in this study.

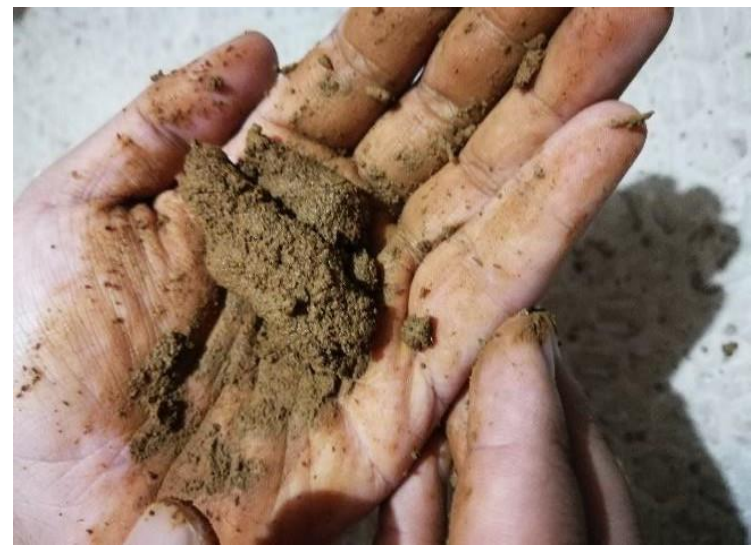

Fig. 1 Soil sample formed in big clumps

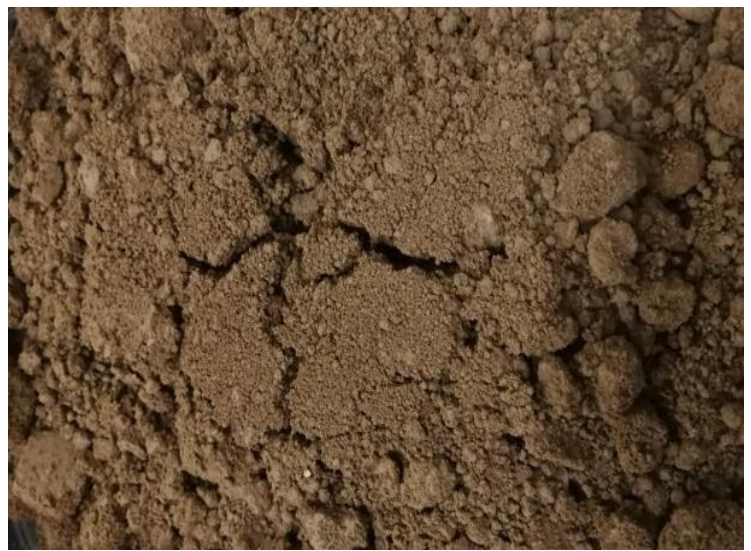

Fig. 2 Crack propagation in soil sample 


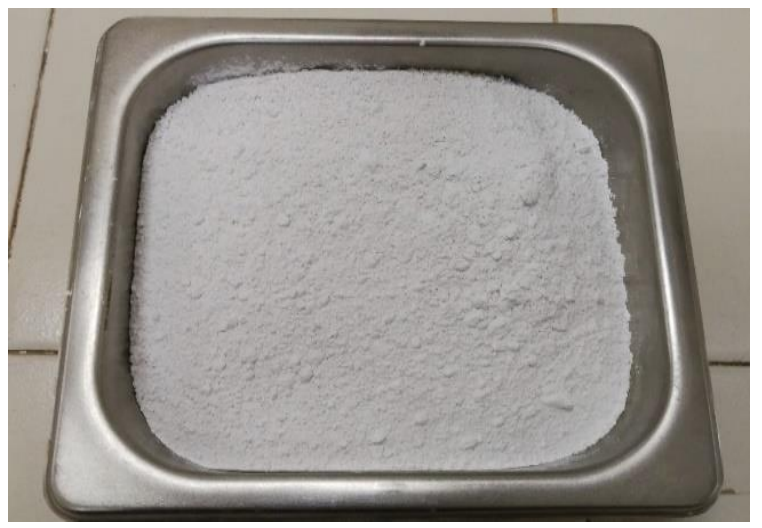

Fig. 3 Recycled powdered gypsum used in the study

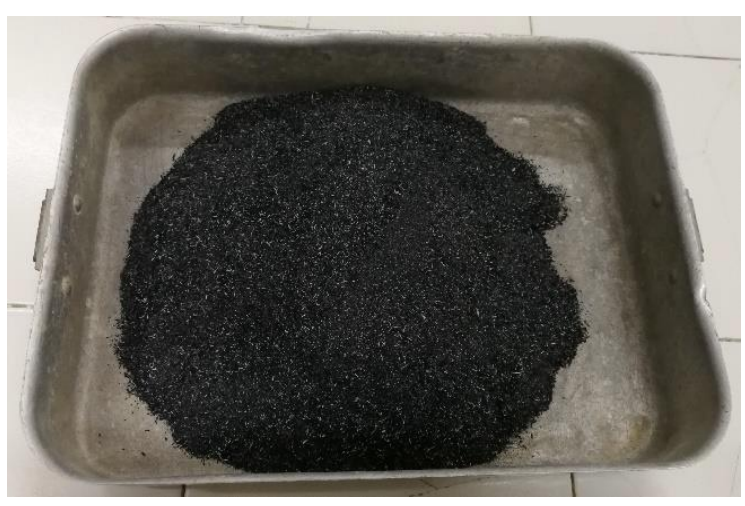

Fig. 4 Rice husk ash sample used in the study

\subsection{Experimental Program}

Considering the objectives of the study, the essential parameters to be determined are the soaked CBR index and coefficient of permeability of the untreated and treated soil specimens. But before conducting the main experimental program, preliminary experiments per ASTM Standards must be done. These experiments are summarized in Table 1.

Table 1 Preliminary Experiments

\begin{tabular}{cc}
\hline Laboratory Test & $\begin{array}{c}\text { ASTM } \\
\text { Standard }\end{array}$ \\
\hline Grain Size Analysis & ASTM D422 \\
Moisture-Density & ASTM D698 \\
Relationship & \\
Maximum Index Density & ASTM D4253 \\
Minimum Index Density & ASTM D4254 \\
\hline
\end{tabular}

Using the results of these tests, the soaked CBR index and coefficient of permeability of all the soil specimens were analyzed and compared. The parameters obtained in these tests were also used to determine if the soil passed the requirements mandated by the Department of Public Works and Highways (DPWH). Table 2 and Table 3 summarize the requirements for the subgrade and subbase layer.

Table 2 Summary of Subgrade Requirements

\begin{tabular}{cc}
\hline \multicolumn{2}{c}{ Subgrade Course } \\
\hline Laboratory Test & Requirement \\
\hline Grain Size Analysis & All particles shall pass \\
& 75 mm square \\
& openings and not \\
& more than 15\% \\
& passing no. 200 sieve \\
\hline Atterberg Limits & Plasticity Index of not \\
& more than 6. Liquid \\
& Limit of not more \\
& than 30. \\
\hline
\end{tabular}

Table 3 Summary of Subbase Requirements

\begin{tabular}{|c|c|}
\hline \multicolumn{2}{|c|}{ Subbase Course } \\
\hline Laboratory Test & Requirement \\
\hline $\begin{array}{l}\text { Grain Size } \\
\text { Distribution }\end{array}$ & $\begin{array}{c}\text { Percent passing no. } \\
200 \text { sieve shall not be } \\
\text { greater than two-thirds } \\
\text { of the percent passing } \\
\text { no. } 40 \text { sieve }\end{array}$ \\
\hline Atterberg Limits & $\begin{array}{c}\text { Percent passing no. } 40 \\
\text { sieve shall have } \mathrm{PI}< \\
12 \text { and } \mathrm{LL}<35\end{array}$ \\
\hline CBR Test & $\begin{array}{c}\text { Soaked CBR values } \\
\text { not less than } 30 \%\end{array}$ \\
\hline
\end{tabular}

\section{TEST RESULTS}

\subsection{Grain Size Analysis}

One of the requirements of DPWH standard in determining the applicability of soils as embankment materials are the grain size distribution of the specimen. The soil in this study was tested for its grain size distribution and the average percent passing sieve no. 200 is 59.14\% [5]. Based on the results of tests done, all mix proportions passed the grading requirement for subgrade materials. The particles of treated soil samples have a range of $1.28 \%$ to $5.54 \%$ passing no. 200 sieve. Moreover, upon calculating the twothirds of percent passing no. 40 sieve and comparing it to the percent passing of no. 200 sieve, all treated samples passed the grading requirements of subbase layer. Figure 5 shows the grain size distribution curve of $15 \%$ gypsum $+10 \%$ RHA + soil mix proportion. 


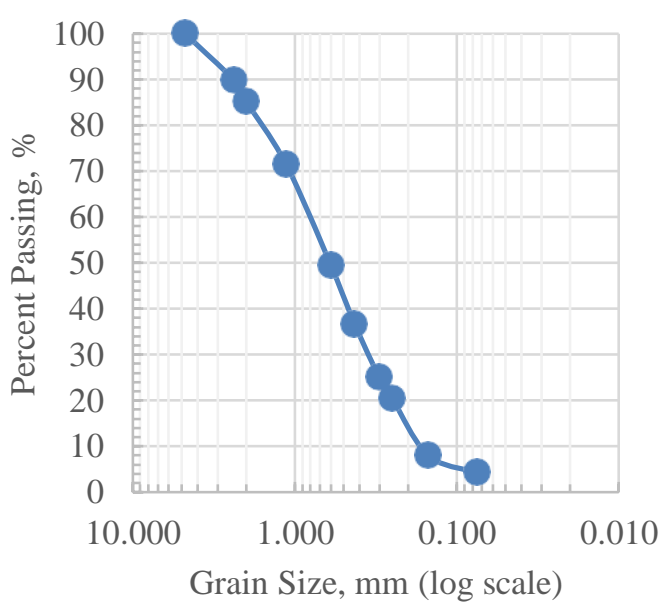

Fig. 5 Grain Size Distribution Curve of Soil Sample $+15 \%$ Gypsum $+10 \%$ RHA

\subsection{Moisture-Density Relationship}

Table 4 summarizes the results of Proctor compaction tests conducted for each mix proportion. Based on the results, it is noticeable that there is an increase in the maximum dry density (MDD) and a decrease in optimum moisture content (OMC) as gypsum is added to the soil sample. The same trend is true as a constant value of $10 \%$ RHA is introduced in the specimen. Typically, the compaction curves of clays are bell-shaped [10]. This can be observed in the compaction curve of plain soil and soil with $15 \%$ gypsum specimens. On the other hand, the addition of RHA in the soil specimens induced the shifting of compaction curves to the left. This kind of compaction curve is common to silt with sand [11]. The change in the trend of the compaction curves proves the effectivity of the admixtures used. Better visualization of the comparison of curves is shown in Figure 6.

Table 4 Average Optimum Moisture Content and Maximum Dry Density of each Soil Mix Proportion

\begin{tabular}{ccc}
\hline Material & $\begin{array}{c}\text { OMC } \\
(\%)\end{array}$ & $\begin{array}{c}\text { MDD } \\
\left(\mathrm{kN} / \mathrm{m}^{3}\right)\end{array}$ \\
\hline Pure Soil & 42.719 & 11.772 \\
\hline $\begin{array}{c}15 \% \text { Gypsum + 85\% Soil } \\
\text { 5\% Gypsum + 10\% RHA } \\
+85 \% \text { Soil }\end{array}$ & 37.374 & 12.681 \\
\hline $\begin{array}{c}\text { 10\% Gypsum + 10\% RHA } \\
+80 \% \text { Soil }\end{array}$ & 32.190 & 13.173 \\
\hline $\begin{array}{c}15 \% \text { Gypsum + 10\% RHA } \\
+75 \% \text { Soil }\end{array}$ & 31.496 & 13.695 \\
\hline
\end{tabular}

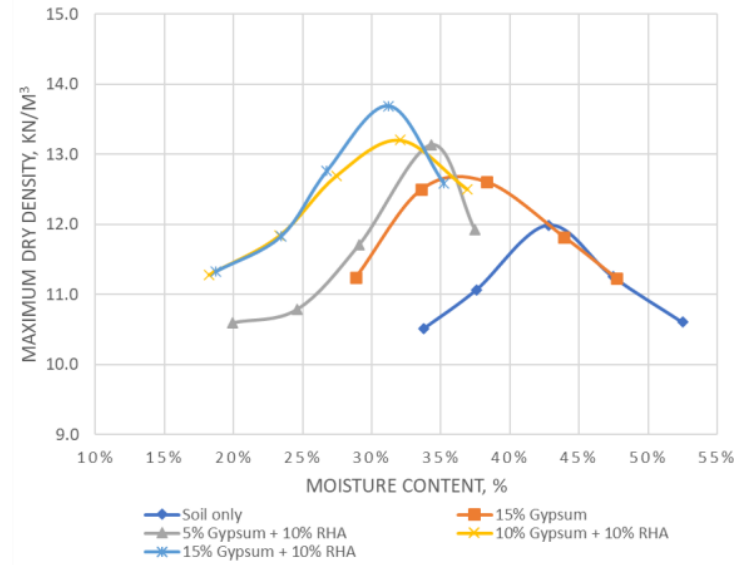

Fig. 6 Comparison of moisture-density curves of untreated and treated soil sample

\subsection{Maximum and Minimum Index Density}

The maximum and minimum index density tests are used to determine the state of compactness of the soil specimen. From the calculated maximum and minimum index densities, the relative density of the specimen is determined. In this study, a constant value of $90 \%$ relative density was used. This is the maximum relative density that can be achieved by manual tamping [11]. The resulting maximum value for $\mathrm{e}_{\max }$ and the resulting minimum value for $\mathrm{e}_{\min }$ in all trials for each mix proportion were adopted. Using these values, the masses of each mix proportion to be used in the permeability test were determined. Table 5 summarizes the resulting values for $\mathrm{e}_{\max }$ and $\mathrm{e}_{\min }$.

Table 5 Maximum and Minimum index densities of each Soil Mix Proportion

\begin{tabular}{ccc}
\hline Material & $\mathrm{e}_{\max }$ & $\mathrm{e}_{\min }$ \\
\hline Pure Soil & 2.554 & 1.616 \\
\hline $15 \%$ Gypsum + 85\% Soil & 2.529 & 1.727 \\
\hline $5 \%$ Gypsum + 10\% RHA + \\
85\% Soil & 2.515 & 1.736 \\
\hline $\begin{array}{c}\text { 10\% Gypsum + 10\% RHA + } \\
80 \% \text { Soil }\end{array}$ & 2.484 & 1.754 \\
\hline $\begin{array}{c}15 \% \text { Gypsum + 10\% RHA + } \\
75 \% \text { Soil }\end{array}$ & 2.476 & 1.692 \\
\hline
\end{tabular}

\subsection{California Bearing Ratio Test}

In assessing the effectiveness of the additives used in this study to stabilize expansive soils, one important factor to consider is its effect on the strength of the soil. In this study, the bearing 
strengths of the untreated and treated soil specimens were determined using the soaked CBR test per ASTM D1883 which is the standard test method for identifying the CBR value of soils. The soil specimens were soaked for 96 hours after compacting them in the CBR mold. Table 6 summarizes the average soaked CBR values of the soil specimens at $2.54 \mathrm{~mm}$ and $5.08 \mathrm{~mm}$ penetrations.

Table 6 Average Soaked CBR Values (\%) of each specimen at $2.54 \mathrm{~mm}$ and $5.08 \mathrm{~mm}$ penetration

\begin{tabular}{ccc}
\hline Material & $\begin{array}{c}\text { CBR @ } \\
2.54 \mathrm{~mm} \\
(\%)\end{array}$ & $\begin{array}{c}\text { CBR @ } \\
5.08 \mathrm{~mm} \\
(\%)\end{array}$ \\
\hline Pure Soil & 1.46 & 1.76 \\
\hline $\begin{array}{c}\text { 15\% Gypsum + 85\% } \\
\text { Soil }\end{array}$ & 2.74 & 2.97 \\
$\begin{array}{c}\text { 5\% Gypsum + 10\% } \\
\text { RHA + 85\% Soil }\end{array}$ & 6.88 & 7.32 \\
\hline $\begin{array}{c}10 \% \text { Gypsum + 10\% } \\
\text { RHA + 80\% Soil }\end{array}$ & 10.72 & 11.13 \\
\hline $\begin{array}{c}15 \% \text { Gypsum + 10\% } \\
\text { RHA + 75\% Soil }\end{array}$ & 20.43 & 21.11 \\
\hline
\end{tabular}

Based on the results, the recorded soaked CBR value for pure soil is $1.76 \%$. This value is considered extremely low for roadway construction but is completely normal for soils classified as $\mathrm{MH}$ (heavy silt). Soaked CBR values ranging from $1.35 \%$ to $2.20 \%$ were recorded for soils classified under MH (heavy silt) [12]. While the addition of $15 \%$ gypsum in the soil specimen yields a $69 \%$ increase in the soaked CBR value of the soil, yet it is still considerably low to pass the roadway construction requirements. On the other hand, the introduction of a constant amount of $10 \%$ RHA in the soil specimen dramatically increases the strength of the soil. At 15\% Gypsum $+10 \%$ RHA sample, which yields the peak average soaked CBR value of $21.11 \%$, a $600 \%$ increase in the soaked CBR value compared to its gypsum-only soil mixture counterpart, was recorded. The bearing strength improvement of $15 \%$ Gypsum $+10 \%$ RHA soil specimens can be used for subgrade fill if it will also allow good drainage for water. However, a minimum of $30 \%$ soaked CBR value must be recorded for subbase application. The failure to reach the required CBR value may be attributed to the grain sizes of the soil specimens. Soil sample in this study is mainly composed of fine-grained particles. Achieving the grading requirements may further increase the soaked CBR of the specimens.

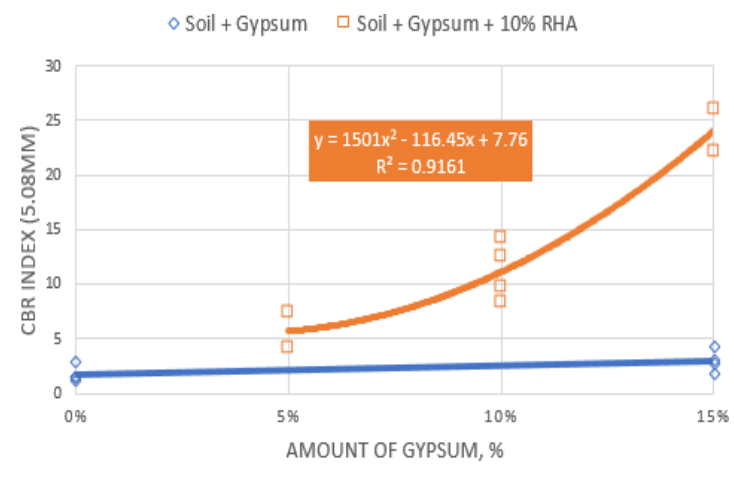

Fig. 7 Correlation between the gypsum content and soaked CBR index at $5.08 \mathrm{~mm}$ penetration for both Gypsum only and Gypsum+10\% RHA samples

In calculating for the CBR index of Gypsum $+10 \%$ RHA soil specimens at $5.08 \mathrm{~mm}$ penetration, Eq. 1 can be used:

$\mathrm{CBR}=1501 \mathrm{xg}^{2}-116.45 \mathrm{xg}+7.76$

Where:

CBR - soaked CBR index at $5.08 \mathrm{~mm}$ penetration $\mathrm{X}_{\mathrm{g}}-$ the amount of gypsum in decimal form

\subsection{Falling Head Permeability Test}

The coefficient of permeability, $\mathrm{k}$, of the treated and untreated soil specimens were determined using a rigid wall permeameter with an internal diameter of $6.305 \mathrm{~cm}$ and a specimen height of $14.6 \mathrm{~cm}$. The condition of the permeability tests was falling head at a constant minimum hydraulic gradient of 1.5. Moreover, a constant relative density of $90 \%$ was achieved in all test specimens as it was the highest value attainable by manual thumping [11]. The coefficient of permeability, $\mathrm{k}$, was calculated using Darcy's Law. Table 7 shows the summary of the coefficient of permeability of the untreated and treated soil specimens.

Table 7 Average Coefficient of Permeability of each soil specimen

\begin{tabular}{cc}
\hline Material & Permeability, cm/s \\
\hline Pure Soil & $\mathbf{3 . 9 5 8} \times \mathbf{1 0}^{-\mathbf{4}}$ \\
\hline $\begin{array}{c}15 \% \text { Gypsum + 85\% Soil } \\
\text { 5\% Gypsum + 10\% RHA } \\
+85 \% \text { Soil }\end{array}$ & $\mathbf{8 . 9 4 3} \times \mathbf{1 0}^{-\mathbf{3}}$ \\
\hline $\begin{array}{c}\text { 10\% Gypsum + 10\% } \\
\text { RHA + 80\% Soil }\end{array}$ & $\mathbf{2 . 3 0 8 \times \mathbf { 1 0 } ^ { - \mathbf { 3 } }}$ \\
\hline $\begin{array}{c}15 \% \text { Gypsum + 10\% } \\
\text { RHA + 75\% Soil }\end{array}$ & $\mathbf{2 . 9 6 0 \times \mathbf { 1 0 } ^ { - \mathbf { 3 } }}$ \\
\hline
\end{tabular}


Based on the results, pure soil sample recorded a coefficient of permeability value of $3.958 \times$ $10^{-4} \mathrm{~cm} / \mathrm{s}$ which is classified as poor in the table of drainage characteristics of soils [13]. The addition of $15 \%$ Gypsum in the soil yields a significant increase in the $\mathrm{k}$ value and improved the drainage capacity of soil into good. Further increase in the permeability was recorded for gypsum $+10 \%$ RHA soil specimens. As the amount of gypsum increases, the coefficient of permeability also increases. A peak value of $3.114 \times 10^{-3} \mathrm{~cm} / \mathrm{s}$ and an average value of $2.960 \times 10^{-3}$ was attained by $15 \%$ Gypsum $+10 \%$ RHA soil specimens which are considered as good drainage capacity. This is $647.85 \%$ greater than the pure soil specimen and $85.11 \%$ greater than the gypsum-only soil specimen counterpart.

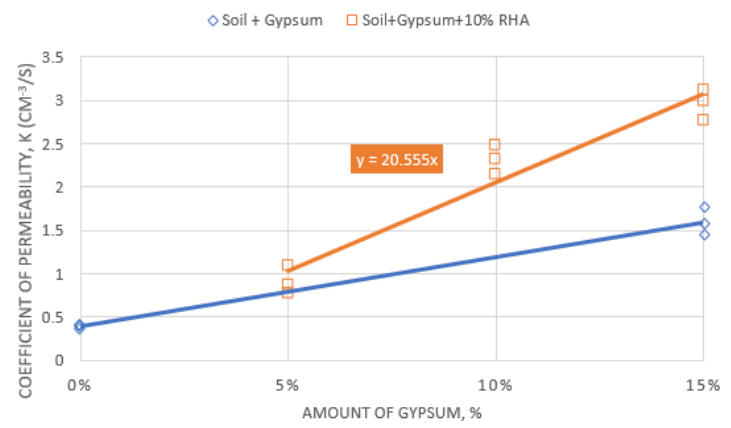

Fig. 8 Correlation between the gypsum content and Coefficient of Permeability for both Gypsum only and Gypsum $+10 \%$ RHA samples

In calculating the coefficient of permeability of Gypsum $+10 \%$ RHA soil specimens, Eq. 2 can be used:

$\mathrm{k}=20.555 \mathrm{xg}$

Where:

$\mathrm{k}$ - coefficient of permeability of Gypsum $+10 \%$ RHA soil specimens

$\mathrm{x}_{\mathrm{g}}$ - the amount of gypsum in percentage (\%)

\section{CONCLUSION}

Based on this study, the following conclusions can be drawn:

Physical properties of the soil were described. Color streaks of the soil were left when molded into bigger clumps. When dried, visible cracks and loss in volume in the soil were also observed. Based on the Unified Soil Classification System (USCS), soil from Kauswagan is classified as MH (high plasticity silt). These characteristics proved that the soil is expansive.

For the bearing capacity, pure soil has a very low soaked CBR value of $1.76 \%$. The addition of $15 \%$ gypsum in the soil resulted in a $69 \%$ increase in the soaked CBR index but still considerably low to pass the roadway construction requirements. On the other hand, the introduction of 10\% RHA in the mix proportion dramatically increased the bearing capacity of soil sample. An increasing soaked CBR index trend was observed as the number of gypsum increases in the mix proportion. A peak average value of $21.11 \%$ was recorded for $15 \%$ Gypsum $+10 \%$ RHA soil specimens. Therefore, the optimum mix proportion in improving the strength property of expansive soil is $15 \%$ Gypsum $+10 \%$ RHA mix.

Expansive soil sample was also tested for its coefficient of permeability, and it showed that it has a poor drainage capacity. The addition of $15 \%$ gypsum reduces the number of voids present in the soil but slightly increases the permeability of the soil. This unusual effect on the soil remains consistent as $10 \%$ RHA was added to the soil. As the amount of gypsum increases in Gypsum $+10 \%$ RHA soil specimens, the void ratio and coefficient of permeability of the soil increases. A peak value of $3.114 \times 10^{-3} \mathrm{~cm} / \mathrm{s}$ and an average value of $2.960 \times 10^{-3}$ was attained by $15 \%$ Gypsum $+10 \%$ RHA soil specimens which are considered as good drainage capacity. Therefore, the optimum mix proportion in improving the permeability characteristics of the expansive soil is $15 \%$ Gypsum $+10 \%$ RHA. The addition of RHA in the mix proportion, which is bigger than the soil, reduced the cohesion among soil particles which creates micropores in the soil specimen

Considering the improvement of the strength and permeability characteristics of soil from Kauswagan due to the combination of gypsum and RHA, the soil is recommended for subgrade use.

\section{ACKNOWLEDGMENTS}

The authors would like to express their deepest gratitude to DOST-ERDTR for providing the necessary resources to complete this research, DLSU-Geotechnical Laboratory Professors and Technicians, ABC Infrageoservices, and to Engr. Jonathan Tiongson for the procurement of materials.

\section{REFERENCES}

[1] Dang, L., Hasan, H., Fatahi, B., Jones, R., \& Khabbaz, H., Enhancing the Engineering Properties of Expansive Soil Using Bagasse Ash and Hydrated Lime. International Journal of GEOMATE, Vol. 11, Issue 25, 2016, pp. 2447 2454. 
[2] Shi, B., Zheng, C., \& Wu, J., Research Progress on Expansive Soil Cracks under Changing Environment. The Scientific World Journal, 2014.

[3] Ahmed, A., Ugai, K., \& Kamei, T., Investigation of recycled gypsum in conjunction with waste plastic trays for ground improvement. Construction and Building Materials, Volume 25, pp. 208-217.

[4] Ahmed, A., Ugai, K., \& Kamei, T., Laboratory and Field Evaluations of Recycled Gypsum as a Stabilizer Agent in Embankment Construction. Soils and Foundations, Volume 51, Issue 6, 2011, pp. 975-990.

[5] Tan, J. F., \& Adajar, M. A. Q., Recycled Gypsum and Rice Husk Ash as Additives in the Stabilization of Expansive Soil. International Journal of GEOMATE, Volume 18, Issue 70, 2020, pp. 197-202.

[6] Behak, L., Soil Stabilization with Rice Husk Ash. Rice Technology and Production, 2017, pp. 31-45.

[7] Yadav, A. K., Gaurav, K., Kishor, R., \& Suman, S. K., Stabilization of alluvial soil for subgrade using Rice Husk Ash, Sugarcane Bagasse Ash, and Cow Dung Ash for Rural Roads. International Journal of Pavement Research and Technology, Volume 10, 2017, pp. 254-261.
[8] Claisse, P. A., \& Ganjian, E., Gypsum: Prospects for Recycling. Proceedings of the ICE - Construction Materials, Volume 159, Issue 1, 2006, pp. 3-4.

[9] Finch, H. J. S., Samuel, A. M., \& Lane, G. P. F., Lockhart \& Wiseman's Crop Husbandry Including Grassland, 9th ed., Woodhead Publishing, 2014.

[10] Budhu, M., Soil Mechanics and Foundations, 3rd ed., John Wiley \& Sons, Inc., 2010.

[11] Dungca, J. R., \& Jao, J. L., Strength and permeability characteristics of road base materials blended with fly ash and bottom ash. International Journal of GEOMATE, Volume 12, Issue 31, 2017, pp. 9-15.

[12] Nagaraj, H. B., \& Suresh, M, Influence of clay mineralogy on the relationship of CBR of finegrained soils with their index and engineering properties. Transportation Geotechnics, Volume 15,2018 , pp. $29-38$

[13] Liu, C., \& Evett, J. B., Soil Properties: Testing, Measurement, and Evaluation, 6th ed., Pearson Education, Inc., 2009.

Copyright (C) Int. J. of GEOMATE All rights reserved, including making copies unless permission is obtained from the copyright proprietors. 